\title{
An Analysis of Conflict and Cooperation in Rare Earth Policy in China: From the Perspective of Liberalism
}

\author{
Mengxuan $\mathrm{Bao}^{1, \mathrm{a}, \uparrow, *}$, Yening Zhong ${ }^{2, \mathrm{c}, \uparrow, *}$ \\ ${ }^{1}$ Hangzhou No.14 High School AP Center, Hangzhou, 694233, China \\ ${ }^{2}$ Sun Yat-sen University, Guangzhou, 510275, China

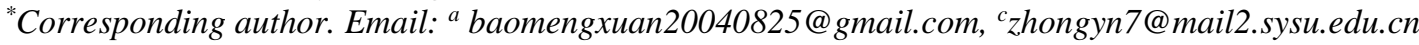 \\ These authors contributed equally.
}

\begin{abstract}
The essay is to explore conflicts and cooperation in terms of China's rare earth policy. This phenomenon has been observed in the long-term, and recently, QUAD has established a league of rare earth, which influences this area. The essay uses the case study method. Through the case study of China, the essay hopes to have broader lessons of rare earth cooperation in the world. The result of the essay reveals the conflicts. Also, the conflicts can be resolved by international negotiation and coordination. Also, the essay reveals that the US is taking an active approach to tackling the changes in rare earth resources in China. In conclusion, the essay deepens our understanding of the present rare earth situation and provides us a new angle to view this issue. Moreover, the essay can be useful to propose changes to the behaviors of nation state actors. The essay presents how international cooperation and competition can take place in the issue of critical material. Admittedly, the essay is limited because there is not enough evidence, and it only focuses on China, so it may not apply perfectly in other countries. Further studies can look into rare earth policies in other countries.
\end{abstract}

Keywords: International relationship, rare earth, global environment, China

\section{INTRODUCTION}

The research we are going to unfold about this topic is the conflicts about rare earth policy in China and other regions and the reasons and resolutions related to conflicts. The research question is so cryptic because it is researched and does not have much evidence. Some nations choose to hide their real statistics about rare earth reservations to avoid conflicts with other countries because rare earth is a significant material in building cutting-edge technology. So each country chooses to conceal its power, with or without abundant rare earth reservations. The United Nations also have little information about the real situations of rare earth.

The research question focused on rare earth in terms of global sustainable development as it is a nonrenewable resource and is so limited in the world. Global organizations need to keep an unblocked global rare earth value chain. No single country can monopolize the resources as a whole, and no several nations can form an oligopoly and increase the market price then. QUAD (Quadrilateral Security Dialogue) has established a league of rare earth, and REIA (Rare Earth International
Association) is the biggest international organization now.

This essay will focus on rare earth situation in China because China is one of the few countries with comprehensive rare earth reservations and has a huge amount of export. China is the best representative among the countries with rare earth reserves of varying degrees, meaning that this case applies to other rare earth exporters.

This topic matters because it deepens our understanding of the present rare earth situation and provides us a new angle to anatomize this issue. Also, it makes possible predictions about future international relations as rare earth can make inventions that can change the world.

This essay is divided into several sections. After the introduction, section I will first provide the context of rare earth elements. Then section II will discuss this phenomenon of conflict on rare earth elements from the perspective of China. After that, section III will analyze how the U.S. deals with the rare earth element conflict. Next, section IV will explain the competition of rare earth conflict. Section V will focus on the cooperation of rare 
earth conflict. The conclusion will discuss future studies about this issue.

\section{RARE EARTH RESOURCES IN CHINA}

According to Wubbeke, Rare earth element (REE) is a generic term for seventeen metallic elements, such as yttrium and scandium, in the earth's crust. This group is divided into two sections, which are light REE and heavy REE [1]. There are comprehensive sayings about the affiliation and classification of the rare earth. Each statement has its own evidence and significance in the classification of the rare earth. For example, according to DOE (U.S. Department of Energy), rare earth elements belong to critical materials (Critical), which is the term used to describe the single elements that have importance to environments and great economic values [2].

Rare earth, however, is abundant in the crust and distributes widely around the globe. Rare earth is mostly distributed in China, Russia, North America, Brazil, and Australia. Even if it is widely scattered globally, these countries have different amounts of rare earth reservations and different market shares. In particular, China is the monopolist of the rare earth resources since it controls nearly seventy percent of the rare earth as a whole. You can infer the proportionality of other countries in the rare earth. Besides, China is also the largest rare earth exporter and completely regulates rare earth trends in the global markets. According to Tse, even though China's share of global production of rare earth has been slightly declined about 10 percent from 2009 to 2012 , it still places in the dominant position. Because China, as an absolute monopolist, can never abandon the command to the rare earth raw materials that can be used to produce highly sophisticated technology [3]. Therefore, China's dominance and influence on the rare earth resources makes it the best object in a case study since it is the most persuasive representative among the countries with rare earth reservations.

According to Kingsnorth, apart from rare earth production, China is also the leading country for rare earth consumption in which it uses 70 percent of the rare earth and export the remaining 30 percent [4]. China, however, spends most of its rare earth consumption on relatively low-level products, such as household appliances and basic social infrastructures. By contrast, Japan is the country with low rare earth production. Still, it uses half of the raw materials of rare earth that imports from China on high-sophisticated industries, such as metallurgical and military industries. From the comparison between the use of rare earth in Japan and China, the problem emerged. Even though China accounts for a large amount of rare earth production, it does not have remarkable advantages in the products made from rare earth because China spends most of the materials on basic industries. Japan, however, even has stronger strengths in high-grade technologies than China as it puts nearly all of the inputs to those industries even they are not quantitatively advantageous. China needs to attach more importance to this issue because its advantage in rare earth production will be eradicated if it only uses it to build infrastructure rather than hightechnologies.

With the development of high-technology industries of other countries by using limited raw materials of rare earth, China has been set quota rent and taxation to exporting rare earth resources. The reason is simple that China wants to continue to maintain the lead of rare earth production and exportation. Therefore, it needs to control the exporting quantity of rare earth to curb the potential development of other countries that might create threats to China. Nevertheless, setting quota rents and increasing tariffs serve different functions, as one aimed to restrain the development of other nations and the other seeks to promote development in domestic industries in terms of rare earth.

Other importing countries, of course, can never compromise to the declining supply of rare earth of China. According to records of WTO, other importing countries gave out consultations to the United Nations after China reduced forty percent of its rare earth export [5]. Countries like Japan, Russia, and Australia all seek to promote development by using rare earth, which then considerably increase the demand for rare earth materials. They unite together, trying to make negotiations with China with the United Nations' help to increase the rare earth export from China as possible. That is where the conflict forms. On the one hand, China is the determinant to the distribution of rare earth in the world as it controls most of the rare production. So under the cooperation and negotiation with the United Nations, China needs to ensure a satisfactory export of rare earth among countries as China is also responsible for the global security of the rare earth industry chain. On the other hand, China must keep its pace of development, so it is necessary to keep the rare earth resources domestically to a point where China can maximize the profits or development. In that case, China must balance keeping its development and satisfying the demand for other countries.

\section{COMPETITION ON RARE EARTH RESOURCES - CHINA'S ACTION}

According to GATT, "quotas or conditional licensing" are not allowed, which is contradicted with China's export regulation in the 2012 dispute. China defends sustainable development, but other western countries view it as against free trade and discrimination of foreign business [6]. GATT Article XX states that export controls are allowed if they are environmental or resource protection. Using GATT Article XX, China's REE policy aims to prove export control could improve its environment. As for a case of the REE conflict 
between the US and China, according to He, he shows that Chinese export control has led to US government intervention in the REE industry in 2010 [7]. The REE conflict between Japan and China can be traced back to the Diaoyu conflict, which happened in 2011. The Chinese REE embargo against Japan indicated a strategic use of REE to achieve political concessions. Even after the captains' release, China halted shipments to Japan for some weeks. Wubbeke argues geopolitical motives did not guide China's export policy. There are not geopolitical aims when China decides to lower down its quotas. And the export controls do not discriminate between countries. If there is an export quota, China had to set it lower. This argument is powerful. It analysis the correct statistic of China's export quota.

\section{COMPETITION ON RARE EARTH RESOURCES - US'S REACTION}

To deal with the Chinese rare earth elements limitation policy, America works in three areas.

First, domestic: parliamentarians have already raised the rare earth elements problem to push the council to publish the law to encourage the increased production of domestic companies [8]. At the time when the 112th Congress was just running, Congressman Leonard Boswell (Leonard Boswell) introduced the Rare Earth and Critical Materials Revival Act of 2011 (H. R. 618) on February 10, 2011. The bill proposes that the Ministry of Energy formulate rare earth research and development and commercial application plan to ensure the long-term, safe and sustainable supply of domestic rare earth materials. On April 6, Congressman Mike Kaufman once again proposed the Rare Earth Supply Chain Technology and Resource Transformation Act of 2011 (H.R. 1388), to establish a competitive domestic rare earth production system and consolidate the national defense supply chain. Such policies have already restarted the production of Mountain Pass_ — the biggest pit of America. They will still encourage American companies to increase their rare earth production to ensure the sufficient supply to support American high tech industries.

Secondly, International: America is searching for cooperators worldwide to support rare earth elements. At present, the United States is actively expanding the supply channels of rare earth around the world. In this process, Australia, a major resource of rare earth, has favored the United States. During the Australia-US Ministerial Consultation in early November 2010, the issue of rare earth became one topic. At the same time, Japan has also become a major partner of the United States due to its advanced rare earth processing technology. On November 18, 2010, the Japanese Minister of Economy, Trade, and Industry Akhiro Ohta and the visiting U.S. Secretary of Energy Steven Chu signed a joint statement on the topic of new energy cooperation, mentioning that Japan and the United States will strengthen cooperation in the fields of rare earth mining and alternative materials research. However, due to the scarcity of rare earth and the increase in demand, fierce competition will become the tide of the rare earth industry. And the conflict will main appear inside the western developed countries because all of these countries have high demand (the demand to keep their advantage of high tech industries) and low production of REE. Consequently, cooperation will not last for a long period inside the western world.

\section{EXPLAINING REE COMPETITION}

REE competition can be interpreted in some ways. In the view of realism, it can be explained as competition for interests. Also, it signifies the science and technology competition in the high-tech industry. As for the appropriate policy solutions, different theories have different explanations. Liberalism argues that the fierce REE competition can be solved through cooperation among countries, regimes, and also consultations. While realism argues that it will increase the conflict, which will lead to trade war etc.

The first explanation is involved in climate change and the use of clean energy. According to Kalantzakos, the goal of decarbonization of the global economy is set. In 2019, major economies (the EU, China, Japan, Korea), even the United States who has now rejoined the Paris Accord, announced their goals to reach climate neutrality mid-century [9]. Such goals impact the global demand for clean energy and raise REE usage, which will lead to more competition. According to a 2020 World Bank report, the production of lithium and cobalt may increase by $500 \%$ by 2050 to meet clean energy demand [10]. From the perspective of decarbonization of the global economy, the objective of decarbonization increases the use of clean energy, which then increases the demand for rare earth resources. Deficiency and then intense competition might be formed as a result of the increasing demand. The strength of this explanation is that it points out the reasons for increasing competition toward rare earth. But there is no obvious relationship between the increasing use of clean energy and rare earth resources.

Second, according to Kalantzakos, the deployment of artificial intelligence (AI) and 5G networks have played an important role in the fourth industrial revolution earlier than expected. The global pandemic COVID is also a big push. Under the background of technology development, wireless technology has evolved from $1 \mathrm{G}$ to $4 \mathrm{G}$ quickly. Compared with $4 \mathrm{G}, 5 \mathrm{G}$ stand out to operate at frequencies above those by $4 \mathrm{G}$ networks. According to Ecclestone, Erbium-doped optical silicaglass fibres are the element in Erbium-doped fibre amplifiers (EDFAs), widely applied in optical communications. So the rare earth Erbium is of great importance in $5 \mathrm{G}$ networks [11]. From the perspective of the fourth industrial revolution and $5 \mathrm{G}$ networks, REE 
competition means seizing the high tech Highlands, so it needs to control enough rare earth resources. This explanation connects $5 \mathrm{G}$ and REE directly but ignores the change of national strength.

The third competition explanation is related to China's rise. It increases assertiveness aggressive to the US. China's rise has exacerbated US-China $5 \mathrm{G}$ race, which is dependent on critical material including rare earth. From the perspective of China's rise, REE competition is distinguished from the traditional competition and can be explained in unconventional areas.

\section{INTERNATIONAL COOPERATION ON RARE EARTH RESOURCES}

The existing international cooperation organizations on rare earth element such as REIA provide platforms for the collaboration between countries but is still limited. Therefore its influence and effect are not profound. And also, China is holding the World Summit on Rare Earth Element. Nevertheless, such a summit is focused on interactions with the non-governmental actors, which does not provide international institutions between the governments.

According to Lee and Ott, Korea Institute for Rare Metals and Ames Laboratory (AMES) are making strategies of rare earth resources regarding research and development [12]. Such cooperation between the U.S between Korea indicates the ambition of the U.S. to take the leadership in rare earth research. In the strategy, the solution on the rare earth elements could be holding international workshops. We believe that this solution can be effective because it may intensify the communication between the countries. Another solution is to find alternatives and develop circular economics. We think this solution may come to effective in the long term. Nevertheless, it will meet challenges in the short term because there are no practical trajectories to realize it. Also, institutional support is lack.

The current international organizations such as World Trade Organization are putting pressure on China. And China still does not have the power to make rules and institutions on international cooperation. China has a big reserve of the rare earth element, and in order to make use of such resource, China should seek to play a more active role in the building and development of rare earth resource cooperation.

To cope with the challenge in rare earth resources, countries should strengthen cooperation in three perspectives. Firstly, realism should not be the main factor, and national interest should not justify irresponsible behaviour in rare earth policymaking. Secondly, abandoning economic interdependence is not the effective solution to the rare earth challenge. Thirdly, rare earth development should not only be dominated by the developed countries. Developing countries should be inclusive in tackling the rare earth challenge globally. Competition on rare earth elements should not be an opportunity to broaden the gap between the developing and developed countries. In the process of the fourth industrialization, developing countries should play an increasingly active role.

\section{CONCLUSION}

In conclusion, the essay deepens our understanding of the rare earth elements and provides a brand new angle to view the rare earth elements. Also, the essay uses the conflict view to explain the phenomenon and the reason for the phenomenon. Furthermore, the essay focuses on the cooperation views and gives the solution to the dilemma.

Besides, the essay deepens our understanding of the rare earth elements and helps us see a clearer future about rare earth elements. In addition, the essay provides another way to understand the present situation, points out the inner logic for the phenomenon. It can help nation state actor to change their behavior.

The essay is useful to make policy recommendations to China regarding rare earth resources. China has big rare earth resource reserves, which will not be likely to change in the short term. The future international competition is about $4 \mathrm{G}$ networks and Artificial Intelligence Competition. In such competition, critical material like rare earth plays an increasingly important role. With the rise of China and its challenge to the US hegemony, the tension on rare earth elements is likely to intensify. Therefore, the coping strategy of China should be to aim to lead the establishment of international order in rare earth resources.

Admittedly, our essay also has its limitations because our comprehension of the whole conflict is still incomplete. Maybe other reasons that were not concluded can also explain the problem. By the way, our case may not conclude all the cases, so there will be some cases that we could not explain very well. About future studies, the goal is to focus more on exporters. However, we can also change to another direction, which is international cooperation.

\section{REFERENCES}

[1] Wübbeke, J. (2013). Rare earth elements in China: Policies and narratives of reinventing an industry. Resources Policy, 38(3), 384-394.

[2] DOE (U.S. Department of Energy) 2011. Critical Materials Strategy.

[3] Tse, P. 2013. 2011 Minerals Yearbook. China [Advance Release], USGS, February. 
[4] Kingsnorth, D.J. 2012. The global rare earths industry: a delicate balancing. Deutsche Rohstoffagentur. Presentation at the Deutsche Rohstoffagentur.16 April. From: 〈www.deutscherohstoffagentur.de/DERA/DE/Dow nloads/RD_kingsnorth_2012.pdf?_blob=publicati onFile $\& v=2\rangle$.

[5] WTO 2012. China-Measures Related to the Exportation of Rare Earths, Tungsten and Molybdenum, DS431.

[6] GATT (General Agreement on Tariffs and Trade) (1994) General agreement on tariffs and trade. From: 〈www.wto.org/english/docs_e/legal_e/06gatt_e.htm $\rangle$.

[7] He, Y. 2013. Coalition for intervention: domestic stakeholder interests in U.S. rare earth trade relations with China. In: Paper presented at the International Studies Association Annual Conference, San Francisco, CA; 3-6 April.

[8] Sun,H; Li,Q. zhong mei xi tu mao yi zheng yi de yuan yin ji ying xiang fen xi. Xian dai guo ji guan xi, 2011 5th. 41-46.

[9] Kalantzakos, 2021. Rare earths, the climate crisis, and tech-imperium. Retrieved from: https://blogs.lse.ac.uk/cff/2021/03/24/rare-earthsthe-climate-crisis-and-tech-imperium/

[10] World Bank Group, 2020. Minerals for Climate Action: The Mineral Intensity of the Clean Energy Transition. Retrieved from: https://pubdocs.worldbank.org/en/9617115888755 36384/Minerals-for-Climate-Action-The-MineralIntensity-of-the-Clean-Energy-Transition.pdf

[11] Ecclestone, 2019. Rare Earths Review Erbium: The Secret Sauce in 5G Networks? Retrieved from: http://www.fullertreacymoney.com/system/data/fil es/PDFs/2019/October/ErbiumReview_Sept2019.p df

[12] Lee, M. H., \& Ott, R. (2016). Report 1: International Cooperation to Development of Strategy and R\&D Collaboration for Substitution of Rare Earth Resources and Report 2: Development of Magnetocaloric Alloys without Critical Elements (No. C-2012-04). Ames Laboratory (AMES), Ames, IA (United States). 